\title{
The Importance of Promoting Digital Literacy in Higher Education
}

\author{
Ana Isabel Santos ${ }^{1}$, Sandro Serpa ${ }^{2}$ \\ ${ }^{1}$ University of the Azores, Faculty of Social Sciences and Humanities, and Interdisciplinary Centre for Childhood and \\ Adolescence - NICA - Uac, Azores, Portugal \\ ${ }^{2}$ University of the Azores, Faculty of Social Sciences and Humanities, and Interdisciplinary Centre of Social Sciences - \\ CICS. UAc/CICS.NOVA. UAc, and Interdisciplinary Centre for Childhood and Adolescence - NICA - UAc, Portugal \\ Correspondence: Sandro Serpa, University of the Azores, Faculty of Social Sciences and Humanities, Department of \\ Sociology, Ponta Delgada, Azores, Portugal.
}

Received: April 5, 2017

doi:10.11114/ijsss.v5i6.2330
Accepted: May 23, $2017 \quad$ Available online: May 24, 2017

URL: https://doi.org/10.11114/ijsss.v5i6.2330

\begin{abstract}
At a time when there is free access to a multitude of information, the knowledge society entails the development and mobilisation of a set of competencies of selection and application of this knowledge in a reasoned and conscious way. It is in this context that higher education should develop its activities, and it is widely recognised that digital literacy encompasses the essential and trans versal abilities to any higher level training, that translate into a good preparation for a successful future professionalization. However, sometimes this does not happen; hence, this short communication seeks to reflect on this problem that is central to the training activity in higher education, analysing some implications of this situation, as well as recommendations.
\end{abstract}

Keywords: digital literacy, higher education, competencies

\section{Introduction}

In a context of development and expansion of an increasingly digital society, training in competencies within the scope of Digital Literacy (DL) of higher education students becomes essential (Jeffrey et al., 2011); yet, it is often viewed as something that "is often taken for granted" (Murray \& Pérez, 2014, p. 95).

This short communication seeks to discuss this problem, especially at a time when the characteristics of students joining higher education are different, both in terms of their training and in terms of their competencies, and also regarding their own expectations, behaviours and values (Andrade, 2016). Why the need to promote DLlearning in higher education?

\section{Essential Relationship between the Development of Digital Literacy and the Promotion of a Scientific Culture in Higher Education}

Presently, we live in a society in which information is, in general, easily accessed by all citizens (Kivunja, 2015; Sparks, Katz, \& Beile, 2016; Silva, Marcial, \& Martins, 2016; Jeffrey et al., 2011), in what may be considered a "digital society" (Martin \& Grudziecke, 2006, p. 249). However, "Governments around the globe are recognizing the economic ramifications of a digitally literate citizenry and implementing systemic strategies to advance digital literacy" (Murray \& Pérez, 2014, p. 85).

This means that access to information is not the same as access to knowledge. Nowadays, it is necessary to be able to select, from all this information, the one that is both true and of interest, so that the individual may form an informed opinion and may have and select options.

This situation becomes especially important in higher education training, whereby students, but also teachers, have to situate consciously in the selection and decision-making on the scientific information that they openly have access to, and which should be guided by its rigor and control, both as a process and as a product.

Even at the political level, the importance of training future professionals in both digital and scientific competencies is acknowledged (Murray \& Pérez, 2014), both at the European level, and specifically in Portugal.

Already in 2003, the European Commission acknowledged that

The ability to use ICT and the Internet becomes a new form of literacy - 'digital literacy'. Digital literacy is 
fast becoming a prerequisite for creativity, innovation and entrepreneurship and without it citizens can neither participate fully in society nor acquire the skills and knowledge necessary to live in the 21st century (European Commission, 2003, p. 3, cit. in Murray \& Pérez, 2014, p. 89).

Also in Portugal, in 2016, the Minister of Science, Technology and Higher Education stated that

it is important to understand how to promote competencies, especially as regards the need to reconcile the development of core competencies in traditional subjects with competencies in information technologies, with social competencies and with the promotion of the ability to learn, apprehend and be entrepreneur [...] It is important to further promote scientific culture (Heitor, 2016, pp. 9-10).

In the process of obtaining information in higher education, while the use of more traditional sources of information, such as books and printed articles, is still valid, the search for digital documentation through the Internet is an increasingly relevant resource, either for its quality or for the fact that physical sources are increasingly fewer, or also, and not less important, because digital publishing is much faster than physical publishing, which makes access to published information more current.

The research on scientifically valid information sources through the Internet presents, in addition to potentialities, also particularities and risks, if not carried out in a reasoned and conscious way. In this sense, it is fundamental that it be carried out by someone that has a critical sense and who is knowledgeable, not only of technical competencies of using virtual libraries or databases of indexed journals but, fundamentally, of competencies and knowledge that allow their careful selection, given the myriad of journals of different quality that are found on the Internet and that may not be automatically discernible by individuals who do not have digital literacy competencies, although they are often expert users of Facebook or the computer (Jeffrey et al., 2011; Murray \& Pérez, 2014).

What are, then, digital literacy competencies in the context of scientific knowledge, a concept that will be our he uristic basis in this reflection? In a somewhat provocative way, we begin by presenting the definition found in Wikipedia (one of the sources of information most often mobilised by students in higher education, frequently in an uncritical way):

Digital literacy is the set of competencies required for full participation in a knowledge society. It includes knowledge, skills, and behaviors involving the effective use of digital devices such as smartphones, tablets, laptops and desktop PCs for purposes of communication, expression, collaboration and advocacy [...] Digital information is a symbolic representation of data, and literacy refers to the ability to read for knowledge, write coherently, and think critically about the written word [...] The individual is able to find, capture, and evaluate information. Digital literacy requires the individual to understand the societal issues raised by digital technologies and possess critical thinking skills (Digital literacy, 2017).

In another more scientifically reasoned proposal for the definition of DL,

Digital Literacy is the awareness, attitude and ability of individuals to appropriately use digital tools and facilities to identify, access, manage, integrate, evaluate, analyse and synthesize digital resources, construct new knowledge, create media expressions, and communicate with others, in the context of specific life situations, in order to enable constructive social action; and to reflect upon this process (Martin, 2006, p. $155)$.

In this sense, for Martin (2006) the concept of DL encompasses a set of competencies and their use in individuals' everyday situations; the fact that such competencies may be at the service of lifelong learning and may be used in specific contexts with which individuals are confronted; various types of literacies such as information literacy, media literacy and visual literacy; and that all these competencies and their mobilisation not only allow them to be put at the service of everyday tasks but also to promote "the ability to reflect on one's own digital literacy development" (p. 155).

Consequently, DL is, currently, essential for social, academic and professional success and will play an increasingly central role in the near future (Murray \& Pérez, 2014; Martin, 2006). Thus, the link between DL and the promotion of a scientific culture, in formal and/or informal environments, both in the face-to-face teaching modality and in online learning processes is, therefore, critical (Prior, Mazanov, Meacheam, Heaslip, \& Hanson, 2016; Knutsson, Blåsjö, Hållsten, \& Karlström, 2012; Kivunja, 2015; Meyers, Erickson, \& Small, 2013; Jeffrey et al., 2011).

Thus, what contribution can higher education provide in the promotion of a DL that allows the construction of learning in any scientific area?

The answer is not simple. Higher education institutions themselves, as well as their teachers, may not be prepared to promote and develop digital literacy competencies in their students. As Murray and Pérez (2014) point out, "At most universities, digital literacy is either taken for granted or assumed to be at an adequate level rather than being assessed, remediated and amplified. The academy must address this inadequacy in incorporating digital literacy as a core, 
foundational competency" (p. 85).

In higher education, besides the characteristics of the teachers, the educational system and the organisation itself, it should not be assumed that students necessarily have a high DL (Argelapós \& Pifarré, 2017; Prior et al., 2016, Khalid \& Pederson, 2016; Sparks et al., 2016). Research reveals that there are different levels, for different motives and reasons.

As an example, we refer to a study carried out with students, even before they get to higher education, on gender differences in the use of digital information in the context of learning purposes. This study concludes that "the participants had a lack of reflection regarding the different actions to solve the digital task. Furthermore, our findings revealed that gender was not associated with differences in digital attainment" (Argelagós \& Pifarré, 2017, p. 1). However, other studies show that this factor, as well as others, influences how digital information is used. For example, Pedro (2007, cit. in Jeffrey et al., 2011) refers to the socio-economic standing, gender and age as variables influencing the possibilities and attitudes towards the use of technology, with consequences in the development of competencies in this field. Furthermore, for Jeffrey et al. (2011), the "beliefs about one's own ability to learn, anxiety about learning, and confidence can hinder learning" (Jeffrey et al., 2011, p. 385).

In sum, and agreeing with Gisbert and Esteve (2011), it is evident that not all university students have the same levels of digital competency and not all of them arrive at higher education with optimal levels in this area.

Faced with this situation, then, what to do? As Gisbert and Esteve (2011) refer, if we consider DL as an essential competency in the training of students, then we must ensure the design and implementation of specific strategies that can provide students with tools that make them progressively more competent both academically and, later, professionally.

In this process, the possibility of performing a diagnostic evaluation that allows identifying the different levels of DL is highlighted as fundamental, intervening intentionally, respecting and starting from the concrete situation of each student.

Ultimately, and because "achieving 21 st century skills requires that the educational experience prepare learners to innovate, create, and contribute to the knowledge economy" (Andrade, 2016, p. 145), higher education institutions should invest on "the adoption of engaging curricular and pedagogical approaches that result in the achievement of learning outcomes $[\ldots]$ such as critical thinking, problem-solving, written and oral communication, collaboration, information literacy, and global competencies"(Andrade, 2016, p. 147).

\section{Conclusions}

As stressed by Murray and Pérez(2014),

many students entering the university today have a high level of exposure to digital technologies and media. However, they are not prepared to cross the bridge between personal and academic use of technology. As academic knowhow is gained through formal education, so too must technological prowess be gained through structured learning experiences (p. 88).

In this sense, it is vital that higher education institutions promote explicit and intentionally reasoned DL de velopment strategies, monetising the competencies that, as users, students and teachers possess, but improving the competencies that allow them to develop criteria for the selection of relevant and pertinent information, respecting the scientific criteria of each area, and enhancing the digital competencies they possess (Sparks et al., 2016).

In any case, it is a matter of intentionally contributing to making higher education students progressively more proficient in the use of technological resources, for their own training, in a logic of development of digital liter acy competencies that effectively contribute to a careful choice of privileged sources of information. This change of paradigm also involves, in our view, the awareness of higher education teachers about the need to intentionally train their students in this sense, because, as Jeffrey et al. (2011, p. 406) posit, "advanced digital information skills are necessary for teachers and students if they are to participate in higher education and lifelong learning".

\section{Acknowledgements}

University of Azores, Interdisciplinary Centre of Social Sciences - CICS.UAc/CICS.NOVA.UAc, UID/SOC/04647/2013, with the financial support of FCT/MEC through national funds and when applicable co-financed by FEDER under the PT2020 Partnership Agreement.

\section{References}

Andrade, M. S. (2016). Curricular elements for learner success-21 st century skills. Journal of Education and Training Studies, 4(8), 143-149. https://doi.org/10.11114/jets.v4i8.1743

Argelagós, E., \& Pifarré, M. (2017). Unravelling secondary students' challenges in digital literacy: Agender perspective. 
Journal of Education and Training Studies, 5(1), 42-55. https://doi.org/10.11114/jets.v5i1.1517

Digital literacy. (2017). In Wikipedia, the free encyclopedia. Retrieved from https://en.wikipedia.org/wiki/Digital_literacy

Gisbert, M., \& Esteve, F. (2011). Digital learners: La competencia digital de los estudiantes universitarios [Digital learners: The digital competence of university students]. La Cuestión Universitaria, 7, 48-59.

Heitor, M. (2016). Resumo da intervenção inicial. Debate temático no Conselho Nacional de Educação sobre ciência, tecnologia e ensino superior no âmbito da apresentação do Plano Nacional de Reformas 8 de junho de 2016 [Summary of the initial intervention. Thematic debate in the National Council of Education on science, technology and higher education in the scope of the presentation of the National Plan of Reforms June 8, 2016]. Ministerio da Ciência, Tecnologia e Ensino Superior [Ministry of Science, Technology and Higher Education]. Retrieved from https://www.google.pt/url?sa=t\&rct=j\&q=\&esrc=s\&source=web\&cd=1\&ved=0ahUKEwjj5ZDW_qrSAhXGMyY KHZ3cDzUQFggbMAA\&url=http\%3A\%2F\%2Fwww.cnedu.pt\%2Fcontent\%2Fnoticias\%2FCNE\%2FDiscurso_M in_Educacao_e_Ciencia_8.Junho.2016.pdf\&usg=AFQjCNEZWNJCSOllEEkWVf7zJg1h10Jr0w\&sig2=DUAZrJ11 m5X93bGlabDzRw\&cad=rja.

Jeffrey, L., Hegarty, B., Kelly, O., Penman, M., Coburn, D., \& McDonald, J. (2011). Developing digital information literacy in higher education: Obstacles and supports. Journal of Information Technology Education, 10, 383-413. Retrieved from ttps://www.google.pt/url?sa=t\&rct=j\&q=\&esrc=s\&source=web\&cd=1\&cad=rja\&uact=8\&ved=0ahUKEwiI38e8sa 7SAhUl8IMKHfb-Dk4QFggeMAA\&url=http\%3A\%2F\%2Fwww.jite.org\%2Fdocuments\%2FVol10\%2FJITEv10p 383-413Jeffrey1019.pdf\&usg=AFQjCNFGaigvooTgEO7JIJUubmYJZ9fw1g\&sig2=0j0u7F46adLL9zmZ7c8GeA.

Khalid, M. S., \& Pederson, M. J. L. (2016). Digital exclusion in higher education contexts: A systematic literature review. Procedia - Social and Behavioral Sciences, 228, 614-621. https://doi.org/10.1016/j.sbspro.2016.07.094

Kivunja, C. (2015). Unpacking the information, media, and technology skills domain of the new learning paradigm. International Journal of Higher Education, 4(1), 166-181. https://doi.org/10.5430/ijhe.v4n1p166

Knutsson, O., Blåsjö, M., Hållsten, S., \& Karlström, P. (2012). Identifying different registers of digital literacy in virtual learning environments. The Internet and Higher Education, 15(4), 237-246. https://doi.org/10.1016/j.iheduc.2011.11.002

Martin, A. (2006). AEuropean framework for digital literacy. Nordic Journal of Digital Literacy, 2(1), 151-161.

Martin, A., \& Grudziecki, J. (2006). DigEuLit: Concepts and tools for digital literacy development, innovation. Teaching and Learning in Information and Computer Sciences, 5(4), 1-19. https://doi.org/10.11120/ital.2006.05040249

Meyers, E. M., Erickson, I., \& Small, R. V. (2013). Digital literacy and informal learning environments: An introduction. Learning, Media and Technology, 38(4), 355-367.https://doi.org/10.1080/17439884.2013.783597

Murray, M. C., \& Pérez, J. (2014). Unravelling the digital literacy paradox: How higher education fails at the fourth literacy. Issues in Informing Science and Information Technology, 11, 85-100. Retrieved from http://iisit.org/Vol11/IISITv11 p085-100Murray0507.pdf

Prior, D. D., Mazanov, J., Meacheam, D., Heaslip, G., \& Hanson, J. (2016). Attitude, digital literacy and self efficacy: Flow-on effects for online learning behavior. Internet and Higher Education, 29, 91-97. https://doi.org/10.1016/j.iheduc.2016.01.001

Silva A. M. da, Marcial, V. F., \& Martins, F. (Ed.). (2016). A literacia da informação em Portugal: Um diagnóstico, um modelo e uma reflexão prospetiva (2007-2010) [Information literacy in Portugal: A diagnosis, a model and a prospective reflection (2007-2010)]. Porto: CETAC.MEDIA / Faculdade de Letras da Universidade do Porto.

Sparks, J. R., Katz, I. R., \& Beile, P. M. (2016). Assessing digital information literacy in higher education: A review of existing frameworks and assessments with recommendations for next-generation assessment (Research Report No. RR-16-32). Princeton, NJ: Educational Testing Service.

\section{Copyrights}

Copyright for this article is retained by the author(s), with first publication rights granted to the journal.

This is an open-access article distributed under the terms and conditions of the Creative Commons Attribution license which permits unrestricted use, distribution, and reproduction in any medium, provided the original work is properly cited. 